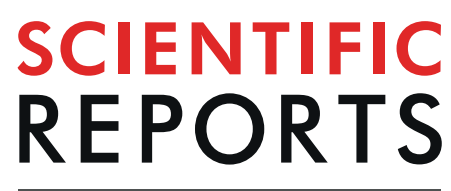

\title{
OPEN The flexible linker of the secreted Flik ruler is required for export switching of the flagellar protein export apparatus
}

\author{
Miki Kinoshita ${ }^{1}$, Seina Tanaka ${ }^{2}$, Yumi Inoue ${ }^{1,5}$, Keiichi Namba $\mathbb{C}^{1,3,4}$, Shin-Ichi Aizawa ${ }^{2}$ \&
} Tohru Minamino $\mathbb{D}^{1 *}$

The hook length of the flagellum is controlled to about $55 \mathrm{~nm}$ in Salmonella. The flagellar type III protein export apparatus secretes FliK to determine hook length during hook assembly and changes its substrate specificity from the hook protein to the filament protein when the hook length has reached about $55 \mathrm{~nm}$. Salmonella FliK consists of an N-terminal domain (Flik ${ }_{\mathrm{N}}$, residues 1-207), a C-terminal domain (FliK ${ }_{C}$ residues 268-405) and a flexible linker (FliK ${ }_{L}$, residues 208-267) connecting these two domains. FliK $_{N}$ is a ruler to measure hook length. FliK $_{C}$ binds to a transmembrane export gate protein FlhB to undergo the export switching. Flik $\mathrm{L}_{\mathrm{L}}$ not only acts as part of the ruler but also contributes to this switching event, but it remains unknown how. Here we report that FliK $_{\mathrm{L}}$ is required for efficient interaction of FliK ${ }_{C}$ with FlhB. Deletions in FliK ${ }_{L}$ not only shortened hook length according to the size of deletions but also caused a loose length control. Deletion of residues 206-265 significantly reduced the binding affinity of $\mathrm{FliK}_{\mathrm{C}}$ for $\mathrm{FlhB}$, thereby producing much longer hooks. We propose that an appropriate length of Flik is required for efficient interaction of $\mathrm{FliK}_{\mathrm{C}}$ with FlhB.

The bacterial flagellar hook is a tubular structure composed of the hook protein FlgE and acts as a universal joint to smoothly transmit torque produced by the flagellar motor to the long helical filament that functions as a propeller ${ }^{1}$. The hook length of the Salmonella flagellum is controlled to about $55 \mathrm{~nm}^{2}$, and the length control is important for the universal joint mechanism ${ }^{3}$.

The flagellar type III protein export apparatus is located at the flagellar base and transports FlgE subunits from the cytoplasm to the distal end of the growing hook structure for hook assembly ${ }^{4,5}$. Newly exported FlgE monomers polymerize onto the nascent hook structure with the help of the hook cap (FlgD), which is located at the hook tip ${ }^{6}$. Interactions between FlgD and FlgE suppress the leakage of FlgE subunits into the culture media so that each FlgE subunit can be efficiently incorporated into the hook structure ${ }^{7,8}$.

When hook length has reached about $55 \mathrm{~nm}$, the flagellar type III protein export apparatus changes its substrate specificity, thereby terminating hook assembly and initiating filament assembly ${ }^{9,10}$. FliK, FlhA, FlhB and Flk are directly involved in the export switching process ${ }^{11-14}$. If certain mutations in FliK, FlhB or FlhA inhibits the export switching of the flagellar type III protein export apparatus, unusually elongated hooks called polyhooks are generated. FlhA and FlhB are transmembrane proteins of the flagellar protein export apparatus ${ }^{15,16}$, and their C-terminal cytoplasmic domains $\left(\mathrm{FlhA}_{\mathrm{C}}, \mathrm{FlhB}_{\mathrm{C}}\right)$ project into the cavity within the basal body $\mathrm{C}$ ring ${ }^{15,16}$. $\mathrm{FlhA}_{\mathrm{C}}$ forms a homo-nonameric ring structure ${ }^{17,18}$ and provides binding-sites for cytoplasmic export components (FliH, FliI, FliJ) ${ }^{19-21}$ and flagellar export chaperones (FlgN, FliS, FliT) in with their cognate substrates ${ }^{22-25}$. Interactions of $\mathrm{FlhA}_{\mathrm{C}}$ with FliH, FliI and FliJ seems to support the strict order of flagellar assembly ${ }^{26,27}$. The interaction of $\mathrm{FlhB}_{\mathrm{C}}$ with FliK induces the export switching of the flagellar type III protein export apparatus ${ }^{28-30}$. FlhB $\mathrm{B}_{\mathrm{C}}$ binds to FliH, FliI, FliJ and export substrates such as FlgD and FlgE ${ }^{19,31,32}$. Conformational changes of FlhA $\mathrm{A}_{\mathrm{C}}$ and $\mathrm{FlhB}_{\mathrm{C}}$

\footnotetext{
${ }^{1}$ Graduate School of Frontier Biosciences, Osaka University, 1-3 Yamadaoka, Suita, Osaka, 565-0871, Japan. ${ }^{2}$ Department of Life Sciences, Prefectural University of Hiroshima, 562 Nanatsuka, Shobara, Hiroshima, 727-0023, Japan. ${ }^{3}$ RIKEN Spring-8 Center and Center for Biosystems Dynamics Research, 1-3 Yamadoaka, Suita, Osaka, 5650871, Japan. ${ }^{4}$ JEOL YOKOGUSHI Research Alliance Laboratories, Osaka University, 1-3 Yamadoaka, Suita, Osaka, 565-0871, Japan. ${ }^{5}$ Present address: Department of Ophthalmology and Visual Sciences, Kyoto University Graduate School of Medicine, Kyoto, 606-8507, Japan. *email: tohru@fbs.osaka-u.ac.jp
} 


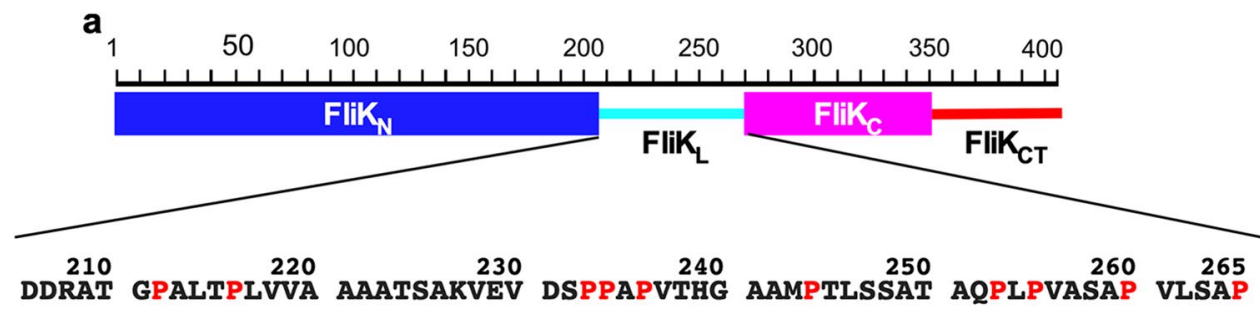

b

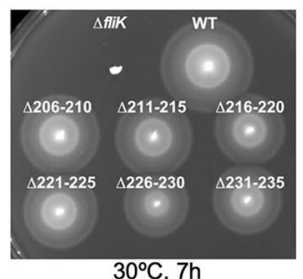

d

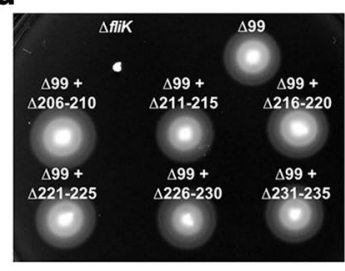

C

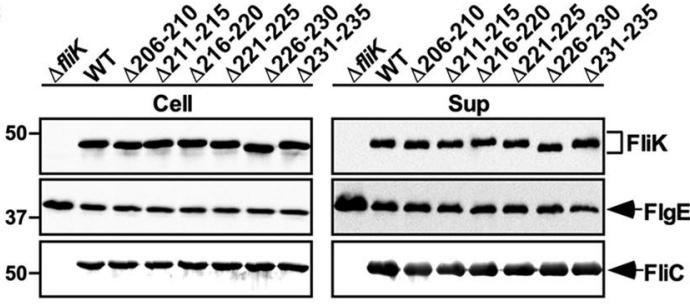

e

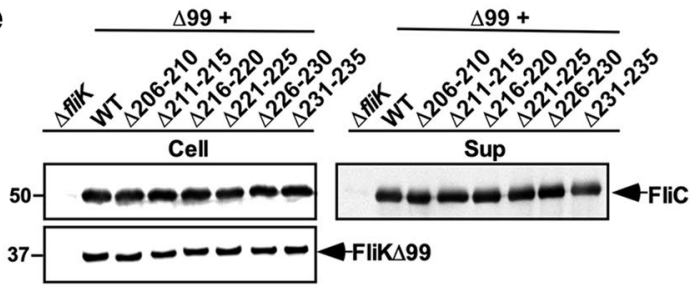

$30^{\circ} \mathrm{C}, 8 \mathrm{~h}$

Figure 1. Effect of deletions of five residues within the $\mathrm{N}$-terminal region of FliK $\mathrm{L}_{\mathrm{L}}$ on FliK function. (a) Domain organization of FliK ruler. FliK consists of the $\mathrm{N}$-terminal ruler domain $\left(\mathrm{FliK}_{\mathrm{N}}\right)$, the C-terminal export switch domain $\left(\mathrm{FliK}_{\mathrm{C}}\right.$ ) and a flexible linker $\left(\mathrm{FliK}_{\mathrm{L}}\right)$ connecting these two domains. FliK $\mathrm{C}_{\mathrm{C}}$ has an intrinsically disordered C-terminal tail $\left(\mathrm{FliK}_{\mathrm{CT}}\right)$. Amino acid sequence of $\mathrm{FliK}_{\mathrm{L}}$ is shown. Proline residues are highlighted in red. (b) Motility of TH8426 harboring pTrc99AFF4 $(\Delta f l i K)$, pMK002 (WT), pMMK1001 ( $\Delta 206-210)$, pMMK1002 ( $\Delta 211-215)$, pMMK1003 ( $\Delta 216-220)$, pMMK1004 ( $\Delta 221-225)$, pMMK1005 $(\Delta 226-230)$ or pMMK1006 $(\Delta 231-235)$ in $0.35 \%$ soft agar. Plates were incubated at $30^{\circ} \mathrm{C}$ for 7 hours. (c) Secretion assays of FliK, FlgE and FliC. Immunoblotting using polyclonal anti-FliK (1st row), anti-FlgE (2nd row) or anti-FliC (3rd row) antibody, of whole cell proteins (Cell) and culture supernatants (Sup) from the above strains. The regions of interest were cropped from original immunoblots shown in Fig. S6a in the Supplemental information using a software, Photoshop CS6, and then the contrast and brightness were adjusted. The positions of molecular mass markers $(\mathrm{kDa})$ are indicated on the left. (d) Motility of TH8426 harboring pTrc99AFF4 $(\Delta f l i K), \mathrm{pNM} 201(\Delta 99)$, pMMK1016 $(\Delta 99+\Delta 206-210)$, pMMK1017 $(\Delta 99+\Delta 211-215)$, pMMK1018 $(\Delta 99+\Delta 216-220)$, pMMK1019 $(\Delta 99+\Delta 221-225)$, pMMK1020 $(\Delta 99+\Delta 226-230)$ or pMMK1021 $(\Delta 99+\Delta 231-235)$ in $0.35 \%$ soft agar containing $1 \mathrm{mM}$ IPTG. Plates were incubated at $30^{\circ} \mathrm{C}$ for 8 hours. (e) Secretion assay of FliC. Immunoblotting using polyclonal anti-FliC (1st row) or anti-FliK (2nd row) antibody, of whole cell proteins (Cell) and culture supernatants (Sup) from the above strains. The regions of interest were cropped from original immunoblots shown in Fig. S6b using Photoshop CS6, and then the contrast and brightness were adjusted.

are required for the substrate specificity switching of the flagellar protein export apparatus upon hook completion ${ }^{18,28,33}$. Flk interferes with premature switching of the protein export apparatus during hook-basal body assembly ${ }^{13,14,34}$

The flagellar type III protein export apparatus transports several FliK molecules during hook assembly to determine hook length in a way that the protein export apparatus switches its substrate specificity when the hook length has reached about $55 \mathrm{~nm}^{35-38}$. Salmonella FliK is a 405 amino-acid protein consisting of the $\mathrm{N}$-terminal ruler domain (FliK $\mathrm{N}_{\mathrm{N}}$, residues 1-207), the C-terminal export switch domain (FliK $\mathrm{C}_{\mathrm{C}}$ residues 268-405) and a flexible linker (FliK $\mathrm{L}_{\mathrm{L}}$, residues 208-267) connecting these two domains (Fig. 1a) ${ }^{39-41}$. FliK $\mathrm{N}_{\mathrm{N}}$ contains a hook-type export signal recognized by the flagellar type III protein export apparatus ${ }^{31,35}$. Insertions and deletions in FliK $_{N}$ make the hook longer and shorter, respectively, suggesting that $\mathrm{FliK}_{\mathrm{N}}$ is a molecular ruler ${ }^{42}$. FliK $\mathrm{K}_{\mathrm{N}}$ binds to FlgD and $\mathrm{FlgE}^{43-45}$, and deletion of residues $129-159$ in FliK ${ }_{\mathrm{N}}$ reduces the binding affinity of FliK for FlgE, thereby producing longer hooks with the filament attached. This suggests that the interaction of $\mathrm{FliK}_{\mathrm{N}}$ with FlgE is required for proper hook length measurement ${ }^{44}$. FliK $\mathrm{C}_{\mathrm{C}}$ consists of a compactly folded core domain consisting of residues 268-352 and an intrinsically disordered C-terminal tail composed of residues 353-405 (FliK ${ }_{\mathrm{CT}}$ ) (Fig. 1a) ${ }^{40,46}$. The core domain of $\mathrm{FliK}_{\mathrm{C}}$ binds to $\mathrm{FlhB}_{\mathrm{C}}$ to allow the flagellar protein export apparatus to switch its substrate specificity from rod- (FlgB, FlgC, FlgF, FlgG, FlgJ, FliE) and hook-type (FlgD, FlgE, FliK) to filament-type (FlgK, FlgL, FlgM, FliC, FliD) $)^{11,12,28,45,47}$. Genetic analyses of FliK $_{\mathrm{CT}}$ have suggested that $\mathrm{FliK}_{\mathrm{CT}}$ controls the export switching activity of FliK $_{\mathrm{C}}$ during hook assembly ${ }^{45,47}$. 
FliK $_{\mathrm{L}}$ contains ten proline residues (Fig. 1a) $)^{39}$ and hence is intrinsically disordered ${ }^{41}$. Hook lengths of the Salmonella fliK $(\Delta 238-269)$ (32 residues deletion) and fliK $(\Delta 248-269)$ (22 residues deletion) mutants are $40.2 \pm 6.1 \mathrm{~nm}[$ mean \pm standard deviation $(\mathrm{SD})]$ and $51.0 \pm 8.8 \mathrm{~nm}$, where their average lengths are shorter than that of the wild-type strain $(52.7 \pm 4.5 \mathrm{~nm})^{42}$. The length of the hook produced by the $f l K(\Delta 161-216)$ mutant $(56$ residues deletion) is $48.7 \pm 22.3 \mathrm{~nm}$, where the average is also shorter than that of the wild-type strain by $4 \mathrm{~nm}$. However, the SD value is larger than the wild-type one, indicating a much looser length control of the hook structure ${ }^{42}$. Furthermore, deletions of residues 161-223 and 161-244 cause polyhooks without the filament attached whereas a deletion of residues 208-269 results in the polyhooks with the filament attached (polyhook-filament phenotype) ${ }^{42}$. These observations raise the possibility that FliK $_{\mathrm{L}}$ not only acts as part of the ruler but also contributes to substrate specificity switching of the flagellar protein export apparatus. To clarify this hypothesis, we constructed a series of mutant variants of FliK with in-frame deletions within $\mathrm{FliK}_{\mathrm{L}}$. We show that a proper length of FliK $\mathrm{L}_{\mathrm{L}}$ between FliK $_{\mathrm{N}}$ and $\mathrm{FliK}_{\mathrm{C}}$ is required for efficient interaction of FliK $\mathrm{C}_{\mathrm{C}}$ with $\mathrm{FlhB}_{\mathrm{C}}$.

\section{Results}

Effect of deletions of five amino-acid residues within residues 206-235 on hook length control. It has been shown that the N-terminal portion of $\mathrm{FliK}_{\mathrm{L}}$ is responsible for proper measurement of hook length ${ }^{42}$. To clarify the role of residues $206-235$ of FliK $_{\mathrm{L}}$ in the hook length control, we constructed a series of mutant variants of FliK with sequential 5-amino-acid deletions within a region of residues 206-235, namely FliK $(\Delta 206-210)$, FliK $(\Delta 211-215)$, FliK $(\Delta 216-220),(\Delta 221-225),(\Delta 226-230)$ and FliK $(\Delta 231-235)$ (Table 1$)$. These six fliK deletion variants fully restored motility of the $\Delta f l i K$ mutant in $0.35 \%$ soft agar plates when they were expressed from the pTrc99A-based plasmid (Fig. 1b). Consistently, the levels of FlgE and FliC secreted by these deletion mutants were detected at the wild-type levels (Fig. 1c, 2 nd and $3 \mathrm{rd}$ rows). These fliK deletions did not affect either protein stability or protein secretion into the culture media (Fig. 1c, 1st row). Therefore, we conclude that these in-frame deletions do not affect FliK function at all.

The length of the most extended polypeptide chain is $0.37 \mathrm{~nm}$ per residue. If $\mathrm{FliK}_{\mathrm{L}}$ adopts a fully extended conformation to act as part of the ruler, we predicted that these 5-amino-acid deletions within residues 206-235 of $\mathrm{FliK}_{\mathrm{L}}$ would reduce the hook length by $1.9 \mathrm{~nm}$. Therefore, we measured the hook length of these fliK deletion mutants. The average hook length of the $f l i K(\Delta 206-210)$, fliK( $\Delta 211-215), f l i K(\Delta 216-220), f l i K(\Delta 221-225)$, $f l i K(\Delta 226-230)$ and $f l i K(\Delta 231-235)$ mutants were $48.5 \pm 4.5 \mathrm{~nm}(\mathrm{n}=113), 49.3 \pm 5.2 \mathrm{~nm}(\mathrm{n}=168), 49.0 \pm 5.6 \mathrm{~nm}$ $(\mathrm{n}=130), 48.6 \pm 4.2 \mathrm{~nm}(\mathrm{n}=118), 49.2 \pm 4.2 \mathrm{~nm}(\mathrm{n}=232)$ and $49.6 \pm 5.4 \mathrm{~nm}(\mathrm{n}=126)$, respectively, which were shorter than the length of the wild-type hook $(53.3 \pm 6.5 \mathrm{~nm}, \mathrm{n}=154)$ (Fig. S1). Over-expression of FliK slightly shortens the hook length. In contrast, when the expression level of FliK is reduced, the cell produces polyhooks, sometimes with the filament attached ${ }^{27,48}$. Polyhooks are frequently observed when FlgE is overproduced in wild-type cells ${ }^{27,43}$. Thus, the balance between the secretion levels of FlgE and FliK seems to be critical for the proper termination of the hook assembly. Since 5-amino-acid deletions within residues 206-235 shorten the hook length by $4 \mathrm{~nm}$, which is shorter than the predicted value, we assume that these deletions may affect not only hook length measurements but also the secretion process of FliK by the type III protein export apparatus and/or the export switching process of the protein export apparatus induced by the interaction of $\mathrm{FliK}_{\mathrm{C}}$ with $\mathrm{FlhB}_{\mathrm{C}}$.

To directly test if these 5 amino-acid deletions affect the interaction of $\mathrm{FliK}_{\mathrm{C}}$ with $\mathrm{FlhB}_{\mathrm{C}}$, it is necessary to analyze the protein transport process of FliK and the export switching process of the flagellar type III protein export apparatus separately. To do so, we used a $f l i K(\Delta 2-99)$ allele, which is an export deficient variant of FliK, because it retains the ability to catalyze export switching of the flagellar type III protein export apparatus when over-expressed ${ }^{49}$. We introduced deletions of residues 206-210, 211-215, 216-220, 221-225, 226-230 or 231-235 into the $f l K(\Delta 2-99)$ allele by inverse PCR method and analyzed motility of the $\Delta$ fliK mutant cells over-expressing FliK $(\Delta 2-99)$ with these deletions in the presence of $1 \mathrm{mM}$ isopropyl $\beta$-D-1-thiogalactopyranoside (IPTG). These additional deletions did not affect motility of the cells over-expressing FliK( $\Delta 2-99)$ (Fig. 1d). Consistently, the inner and extracellular amounts of FliC seen in the $f l i K(\Delta 2-99+\Delta 206-210)$, fliK( $\Delta 2-99+\Delta 211-215)$, fliK( $\Delta 2-99+\Delta 216-220)$, $f l i K(\Delta 2-99+\Delta 221-225), f l i K(\Delta 2-99+\Delta 226-230)$ and $f l K(\Delta 2-99+\Delta 231-235)$ cells were the same as those in the fliK( $\Delta 2-99)$ cells (Fig. 1e, 1st row). Since these deletions did not affect the expression level of FliK( $\Delta 2-99)$ (Fig. 1e, 2nd row), we suggest that they do not affect the interaction of $\mathrm{FliK}(\Delta 2-99)$ with $\mathrm{FlhB}_{\mathrm{C}}$. Therefore, we propose that these deletions may affect the protein transport process of FliK as well as hook length measurement.

To further understand the ruler function of residues 206-235 in $\mathrm{FliK}_{\mathrm{L}}$, we constructed larger deletion variants, FliK( $\Delta 206-215)$, FliK( $\Delta 216-225)$, FliK( $\Delta 226-235)$, FliK( $\Delta 206-220)$, FliK( $\Delta 221-235)$ and $\operatorname{FliK}(\Delta 206-235)$ and analyzed their motility in $0.35 \%$ soft agar plates (Fig. S2a). Motility of the $f l K(\Delta 206-215), f l i K(\Delta 226-235)$, $f l i K(\Delta 206-220), f l i K(\Delta 221-235)$ and $f l i K(\Delta 206-235)$ cells was almost the same as wild-type motility whereas that of the $f l K(\Delta 216-225)$ mutant was slightly less than the wild-type level (Fig. S2a). The cellular and secretion levels of these deletion variants were essentially the same as the wild-type levels (Fig. S2b). Because these deletion mutants were expressed from the pTrc99AFF4 vector, it is also possible that their over-expression results in motility comparable to the wild-type level. To verify this possibility, the wild-type $f i K$ allele on the chromosomal DNA was replaced by the $f l i K(\Delta 206-235)$ allele. Motility of the $f l i K(\Delta 206-235)$ mutant was slightly less than that of wild-type cells (Fig. S2c). To test whether the deletion of residues 206-235 affect hook length, we isolated hook-basal bodies from the fliK( $\Delta 206-235)$ mutant and measured the hook length (Figs. 2 and S3). A major peak of the hook length distribution was shifted to a shorter value than that of the wild-type (Fig. 2). While the majority of wild-type hook length was distributed within a range from $50 \mathrm{~nm}$ to $60 \mathrm{~nm}$, the hook length distribution of the $f l K(\Delta 206-235)$ mutant showed a major peak population between $41 \mathrm{~nm}$ and $50 \mathrm{~nm}$. However, longer hooks were also observed albeit shorter than those of polyhooks produced by the $\Delta f l i K$ mutant $[362.8 \pm 200.9 \mathrm{~nm}$ $(\mathrm{N}=146)]$. As a result, the average hook length of the $f l i K(\Delta 206-235)$ mutant was $54.5 \pm 15.5 \mathrm{~nm}(\mathrm{n}=112)$, compared to $53.8 \pm 5.6 \mathrm{~nm}(\mathrm{n}=130)$ for the wild-type. The SD value of the $f l i K(\Delta 206-235)$ mutant was larger than the wild-type one, indicating that the deletion of residues 206-235 in FliK $\mathrm{L}_{\mathrm{L}}$ cause a looser hook length control 


\begin{tabular}{|c|c|c|}
\hline $\begin{array}{l}\text { Strains and } \\
\text { Plasmids }\end{array}$ & Relevant characteristics & $\begin{array}{l}\text { Source or } \\
\text { reference }\end{array}$ \\
\hline \multicolumn{3}{|l|}{ E. coli } \\
\hline BL21 Star (DE3) & Overexpression of proteins & Novagen \\
\hline \multicolumn{3}{|l|}{ Salmonella } \\
\hline SJW1103 & Wild type for motility and chemotaxis & 61 \\
\hline TH8426 & $\Delta f l i K$ & 47 \\
\hline MMK1012 & $f l i K(\Delta 206-235)$ & This study \\
\hline MMK1013 & $f l i K(\Delta 206-245)$ & This study \\
\hline MMK1014 & $f l i K(\Delta 206-255)$ & This study \\
\hline MMK1015 & $f l i K(\Delta 206-265)$ & This study \\
\hline \multicolumn{3}{|l|}{ Plasmids } \\
\hline pTrc99AFF4 & Modified pTrc expression vector & 62 \\
\hline pKM002 & pTrc99AFF4/FliK & 48 \\
\hline pNM201 & pTrc99AFF4/FliK( $\Delta 2-99)$ & 44 \\
\hline pMMK521 & pETDuet-1/FliK(I304amber) + FlhB $_{\mathrm{C}}$ & 45 \\
\hline pMMK1001 & pTrc99AFF4/FliK $(\Delta 206-210)$ & This study \\
\hline pMMK1002 & pTrc99AFF4/FliK( $\Delta 211-215)$ & This study \\
\hline pMMK1003 & pTrc99AFF4/FliK( $\Delta 216-220)$ & This study \\
\hline pMMK1004 & pTrc99AFF4/FliK( $(\Delta 221-225)$ & This study \\
\hline pMMK1005 & pTrc99AFF4/FliK $(\Delta 226-230)$ & This study \\
\hline pMMK1006 & pTrc99AFF4/FliK( $\Delta 231-235)$ & This study \\
\hline pMMK1007 & pTrc99AFF4/FliK( $\Delta 206-215)$ & This study \\
\hline pMMK1008 & pTrc99AFF4/FliK( $(\Delta 216-225)$ & This study \\
\hline pMMK1009 & pTrc99AFF4/FliK( $\Delta 226-235)$ & This study \\
\hline pMMK1010 & pTrc99AFF4/FliK( $\Delta 206-220)$ & This study \\
\hline pMMK1011 & pTrc99AFF4/FliK( $(\Delta 221-235)$ & This study \\
\hline pMMK1012 & pTrc99AFF4/FliK $(\Delta 206-235)$ & This study \\
\hline pMMK1013 & pTrc99AFF4/FliK( $\Delta 206-245)$ & This study \\
\hline pMMK1014 & pTrc99AFF4/FliK( $(\Delta 206-255)$ & This study \\
\hline pMMK1015 & pTrc99AFF4/FliK( $(\Delta 206-265)$ & This study \\
\hline pMMK1015SP & pTrc99AFF4/FliK( $\Delta 206-265 S P)$ & This study \\
\hline pMMK1016 & pTrc99AFF4/FliK( $(\Delta 2-99+\Delta 206-210)$ & This study \\
\hline pMMK1017 & pTrc99AFF4/FliK( $(\Delta 2-99+\Delta 211-215)$ & This study \\
\hline pMMK1018 & pTrc99AFF4/FliK $(\Delta 2-99+\Delta 216-220)$ & This study \\
\hline pMMK1019 & pTrc99AFF4/FliK( $(\Delta 2-99+\Delta 221-225)$ & This study \\
\hline pMMK1020 & pTrc99AFF4/FliK( $(\Delta 2-99+\Delta 226-230)$ & This study \\
\hline pMMK1021 & pTrc99AFF4/FliK $(\Delta 2-99+\Delta 231-235)$ & This study \\
\hline pMMK1022 & pTrc99AFF4/FliK $(\Delta 2-99+\Delta 206-215)$ & This study \\
\hline pMMK1023 & pTrc99AFF4/FliK( $(\Delta 2-99+\Delta 216-225)$ & This study \\
\hline pMMK1024 & pTrc99AFF4/FliK( $(\Delta 2-99+\Delta 226-235)$ & This study \\
\hline pMMK1025 & pTrc99AFF4/FliK $(\Delta 2-99+\Delta 206-220)$ & This study \\
\hline pMMK1026 & pTrc99AFF4/FliK( $(\Delta 2-99+\Delta 221-235)$ & This study \\
\hline pMMK1027 & pTrc99AFF4/FliK( $(\Delta 2-99+\Delta 206-235)$ & This study \\
\hline pMMK1028 & pTrc99AFF4/FliK( $(\Delta 2-99+\Delta 206-245)$ & This study \\
\hline pMMK1029 & pTrc99AFF4/FliK( $(\Delta 2-99+\Delta 206-255)$ & This study \\
\hline pMMK1030 & pTrc99AFF4/FliK( $(\Delta 2-99+\Delta 206-265)$ & This study \\
\hline pMMK1030SP & pTrc99AFF4/FliK( $(\Delta 2-99+\Delta 206-265 \mathrm{SP})$ & This study \\
\hline pMMK1031 & pETDuet-1/FliK( $\Delta 2-99+$ I304amber $)+$ FlhB $_{C}$ & This study \\
\hline pMMK1032 & pETDuet-1/FliK $(\Delta 2-99+\Delta 206-265+$ I304amber $)+$ FlhB $_{\mathrm{C}}$ & This study \\
\hline pMMK1032SP & pETDuet-1//FliK $(\Delta 2-99+\Delta 206-265 \mathrm{SP}+$ I304amber $)+$ FlhB $_{C}$ & This study \\
\hline
\end{tabular}

Table 1. Strains and plasmids used in this study.

than the wild-type. Therefore, we suggest that a deletion of residues 206-235 not only shortens the hook length according to the size of deletion but also affects the interaction of $\mathrm{FliK}_{\mathrm{C}}$ with $\mathrm{FlhB}_{\mathrm{C}}$ during hook assembly.

Effect of much larger deletions within FliK $\mathrm{L}_{\mathrm{L}}$ on hook length control and substrate specificity switching. To clarify the role of Fli $\mathrm{K}_{\mathrm{L}}$ in the export switching process of the flagellar type III protein export apparatus, the wild-type $f l i K$ allele on the chromosome was replaced by the $f l i K(\Delta 206-245)$, fliK( $\Delta 206-255)$ or 
$f l K(\Delta 206-265)$ allele. Motility of these mutants were worse than wild-type motility (Fig. 3a) although the cellular and secreted amounts of FlgE and FliC were detected almost at the wild-type levels (Fig. 3b, 2nd and 3rd rows). Because neither cellular nor extracellular FliK level was affected by these larger deletions within FliK (Fig. 3b, 1st row), this suggests that these deletions reduce FliK function.

To test whether these larger deletions affect the hook length control, we measured the hook length of the fliK( $\Delta 206-245)$, fliK( $\Delta 206-255)$ and $f l i K(\Delta 206-265)$ mutants (Figs. 3c and S3). The hook length distribution of the $f l i K(\Delta 206-245)$ mutant shows a major peak population between $45 \mathrm{~nm}$ and $55 \mathrm{~nm}$. Longer hooks and polyhooks were seen for the $f l i K(\Delta 206-255)$ and $f l i K(\Delta 206-265)$ mutants although shorter hooks were also observed (Fig. S3). As a result, the average hook lengths of the $f l i K(\Delta 206-245)$, fliK( $\Delta 206-255)$ and $f l i K(\Delta 206-$ 265) mutants were $54.4 \pm 17.6 \mathrm{~nm}(\mathrm{n}=226), 75.0 \pm 38.9 \mathrm{~nm}(\mathrm{n}=160)$ and $107.1 \pm 65.0 \mathrm{~nm}(\mathrm{n}=300)$, respectively, indicating that the hook length control becomes worse in the fliK( $\Delta 206-255)$ and $f l i K(\Delta 206-265)$ mutants.

To investigate whether these larger deletions directly affect the export switching function of FliK $\mathrm{C}_{\mathrm{C}}$, we introduces deletions residues 206-245, 206-255 or 206-265 into the fliK( $\Delta 2-99)$ allele. Motility of the cells over-expressing FliK $(\Delta 2-99)$ with these three deletions was reduced significantly (Fig. 3d), and especially the deletion of residues 206-265 reduced the cellular and extracellular levels of FliC by about 3-fold, thereby reducing motility considerably (Fig. 3e). This suggests that these three deletions reduce the export switching function of FliK .

To clarify why the deletion of residues 206-265 considerably reduces the export switching activity of FliK $\mathrm{K}_{\mathrm{C}}$, we isolated fourteen pseudorevertants from the cells over-expressing $\operatorname{FliK}(\Delta 2-99)$ with an in-frame deletion of residues 206-265. Motility of these pseudorevertants was much better than that of its parent cells and was slightly better than that of the cells over-expressing $\operatorname{FliK}(\Delta 2-99)$ (Fig. 4a). Consistently, the cellular and extracellular levels of FliC seen in these pseudorevertants were much higher than those in the $f l K(\Delta 2-99+\Delta 206-265)$ cells and slightly larger than those in the $f l K(\Delta 2-99)$ cells (Fig. 4 b). These results indicate that the suppressor mutations enhance the probability of export switching to occur. DNA sequence analysis revealed that all suppressor mutations are insertion mutation of a DNA fragment encoding 100 amino-acid residues corresponding to residues 111-270 without residues 206-265 due to gene duplication (Fig. 4c). As a result, this intragenic FliK $(\Delta 2-$ $99+\Delta 206-265)$ suppressor mutation variant, namely FliK $(\Delta 2-99+\Delta 206-265$ SP $)$, showed much slower mobility on SDS-PAGE than FliK $(\Delta 2-99)$ and FliK $(\Delta 2-99+\Delta 206-265)$ (Fig. $4 \mathrm{~b})$. The inserted sequence of the suppressor mutant was located between Glu-270 and Trp-271 residues in helix $\alpha 1$ of the core domain of FliK ${ }_{C}$ (Fig. 4d). The $f l i K(\Delta 2-99+\Delta 206-265)$ mutant cells produced polyhooks sometimes with filaments attached (Fig. S4). In contrast, most of the pseudorevertant cells had a few flagella (Fig. S4). The pseudorevertant cells produced normal hooks or much shorter polyhooks compared to the fliK( $\Delta 2-99)$ and $f l i K(\Delta 2-99+\Delta 206-265)$ cells (Fig. S4). Careful measurements of the hook length indicated that the average hook length of the pseudorevertant were $113.4 \pm 136.7 \mathrm{~nm}(\mathrm{n}=308)$, compared to $194.5 \pm 180.4 \mathrm{~nm}(\mathrm{n}=308)$ for the $f l i K(\Delta 2-99)$ cells and $503.1 \pm 281.3 \mathrm{~nm}(\mathrm{n}=301)$ for the $f l i K(\Delta 2-99+\Delta 206-265)$ cells (Figs. 5 and S5). These results led to a conclusion that $\mathrm{FliK}_{\mathrm{L}}$ is required for efficient substrate specificity switching of the flagellar type III protein export apparatus.

Interaction between FliK( $\Delta 2-99)$ and FlhB $_{\mathrm{C}}$. Targeted photo-crosslinking experiments have shown that Val-302 and Ile-304 of FliK $\mathrm{C}_{\mathrm{C}}$ are in relatively close proximity of $\mathrm{FlhB}_{\mathrm{C}}$, allowing FliK to form a photo-crosslinked product with $\mathrm{FlhB}_{\mathrm{C}}{ }^{45}$. To investigate whether the deletion of residues $206-265$ of $\mathrm{FliK}_{\mathrm{L}}$ and its suppressor insertion mutation reduces and increases the binding affinity of $\mathrm{FliK}_{\mathrm{C}}$ for $\mathrm{FlhB}_{\mathrm{C}}$, respectively, we introduced an amber mutation at position 304 of $\operatorname{FliK}(\Delta 2-99)$, FliK $(\Delta 2-99+\Delta 206-265)$ and FliK $(\Delta 2-99+\Delta 206-265 S P)$ to incorporate $p$-benzoyl-phenylalanine (pBPA), which is a photo-reactive phenylalanine and carried out photo-crosslinking experiments. We used FliK(I304amber) as a positive control. FliK(I304pBPA) produced a ca. $53 \mathrm{kDa}$ photo-crosslinked product with $\mathrm{FlhB}_{\mathrm{C}}$ after UV irradiation (Fig. 4e, lane 2), in agreement with a previous report ${ }^{45}$. However, FliK $(\Delta 2-99+\mathrm{I} 304 \mathrm{pBPA})$ did not form any photo-crosslinked products with $\mathrm{FlhB}_{\mathrm{C}}$ (Fig. 4e, lane 4), indicating that the binding affinity of $\mathrm{FliK}(\Delta 2-99)$ for $\mathrm{FlhB}_{\mathrm{C}}$ is lower than that of wild-type FliK. FliK $(\Delta 2-99+\Delta 206-265 \mathrm{SP}+\mathrm{I} 304 \mathrm{pBPA})$ reproducibly formed a $51 \mathrm{kDa}$ photo-crosslinked product along with $\mathrm{FlhB}_{\mathrm{C}}$ (Fig. 4e, lane 8) whereas FliK $(\Delta 2-99+\Delta 206-265+\mathrm{I} 304 \mathrm{pBPA})$ did not (lane 6). This suggests that the inserted sequence of the pseudorevertant increases the binding affinity of FliK $(\Delta 2-99)$ for FlhB ${ }_{C}$ so that the export switching of the type III protein export apparatus occurs more efficiently.

Effect of the 100 residues suppressor insertion on the length of hook produced by the flik( $\Delta$ 206-265) mutant. To investigate whether the insertion mutation of the $f l i K(\Delta 2-99+\Delta 206-265)$ suppressor mutant also improves the export switching function of the fliK( $\Delta 206-265)$ mutant, we introduced the extra 100 amino-acid insertion sequence of the $f l K(\Delta 2-99+\Delta 206-265 S P)$ mutant into the $f l i K(\Delta 206-265)$ allele by the overlap PCR method to generate the $f l i K(\Delta 206-265 S P)$ allele. Motility of the $\Delta f l i K$ mutant harboring pMMK1015SP [FliK( $\Delta 206-265 S P)]$ was better than that of the $\Delta$ fliK mutant harboring pMMK1015 [FliK $(\Delta 206-$ 265)] although it was worse than that of the $\Delta f l K$ mutant transformed with pKM002 (wild-type FliK) (Fig. 6a). Neither cellular nor extracellular FliK level was affected by the inserted sequence (Fig. 6b, 1st row). The amounts of FlgE secreted by the $f l i K(\Delta 206-265 S P)$ mutant were slightly less than that by the $f l i K(\Delta 206-265)$ mutant and almost the same as the wild-type level (Fig. 6b, 2nd and 3rd rows). There was no difference in the cellular and extracellular FliC levels between the $f l i K(\Delta 206-265)$ and $f l i K(\Delta 206-265 S P)$ mutants. These results indicates that the inserted sequence of the $f l i K(\Delta 2-99+\Delta 206-265)$ suppressor mutant is also capable of improving the export switching function of $\mathrm{FliK}(\Delta 206-265)$.

The amino acid sequence of FliK $(\Delta 206-265 \mathrm{SP})$ is longer by 40 amino-acids than that of wild-type FliK, from which the average hook length is predicted to be about $70 \mathrm{~nm}$, thereby reducing motility. To verify this hypothesis, we isolated hook-basal bodies from the $\Delta f l i K$ mutant carrying pMMK1015 [FliK( $\Delta 206-265)]$ or pMMK1015SP 

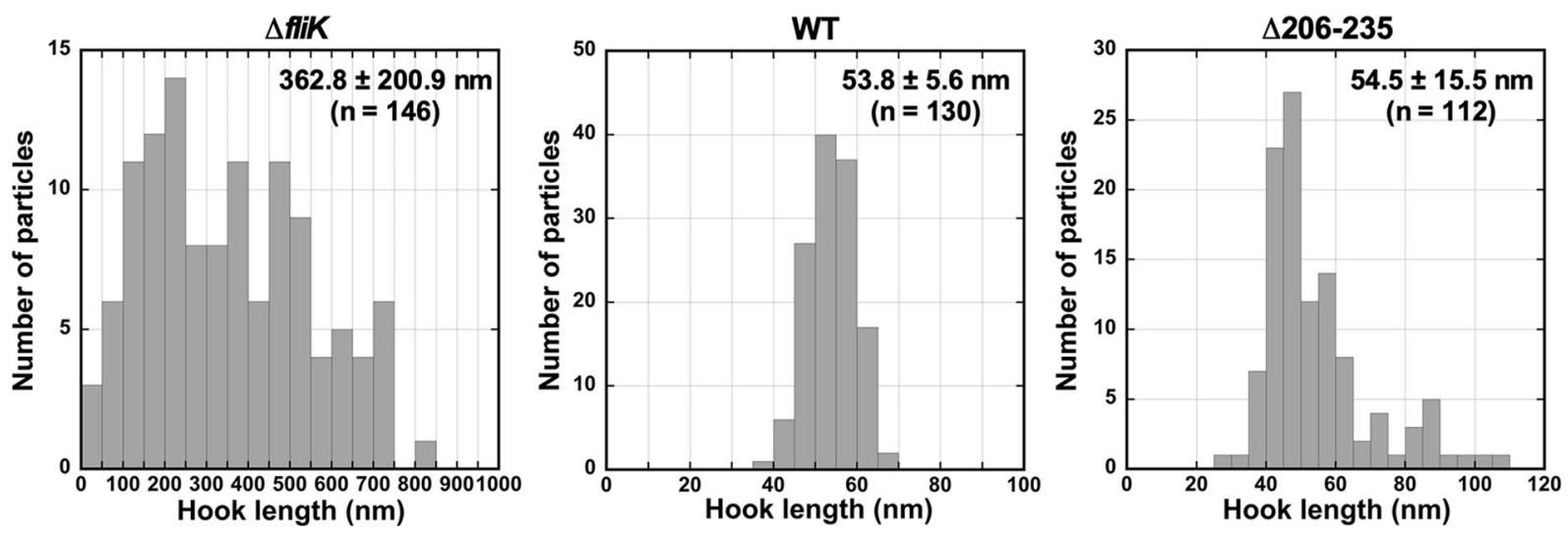

Figure 2. Effect of deletion of residues 206-235 of FliK $\mathrm{L}_{\mathrm{L}}$ on hook length control. Histograms of hook length

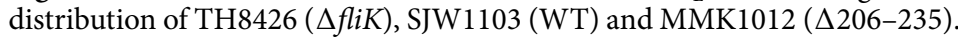

$[$ FliK( $\Delta 206-265 S P)]$ and measured their hook length (Figs. $6 \mathrm{c}$ and S5). The average hook length of the $\Delta f l i K$ mutant carrying pMMK1015 was $225.4 \pm 167.7 \mathrm{~nm}(\mathrm{n}=127)$, which were longer than that of the MMK1015 strain $(107.1 \pm 65.0 \mathrm{~nm})$. Since $\operatorname{FliK}(\Delta 206-265)$ was expressed from the pTrc99AFF4 vector, we assume that such a length difference may be a consequence of the multicopy effect of FliK $(\Delta 206-265 S P)$. The hook length distribution of the $\Delta f l i K$ mutant carrying pMMK1015SP showed a major peak population between $61 \mathrm{~nm}$ and $100 \mathrm{~nm}$, but much longer hooks and polyhooks were observed as well. As a result, the average hook length of the $\Delta f l i K$ mutant carrying pMMK1015SP was $204.0 \pm 183.9 \mathrm{~nm}(\mathrm{n}=518)$, which was shorter than that of the $\Delta f l i K$ mutant carrying pMMK1015. This suggests that the suppressor insertion mutation increases the probability of the interaction between $\mathrm{FliK}_{\mathrm{C}}$ with a deletion of residue 206-265 and $\mathrm{FlhB}_{\mathrm{C}}$, thereby increasing the export switching probability of the flagellar type III protein export apparatus.

\section{Discussion}

The bacterial injectisome directly transports virulence effector proteins into the cytosol of host cells for bacterial infection. The injectisome consists of basal body rings and a tubular structure called the needle and looks similar to the flagellar hook-basal body ${ }^{50}$. The injectisome uses a secreted molecular ruler, SctP (originally referred to as YscP and InvJ in the Yeshinia and Salmonella injectisomes, respectively) to determine the needle length in a way similar to FliK ${ }^{51,52}$. The core domain of FliK $_{\mathrm{C}}$ is conserved among FliK/SctP family ${ }^{53}$ and possesses a fold similar to the C-terminal domain of SctP of the injectisome of Pseudomonas aeruginos $a^{54}$. It has been shown that residues 301-350 of FliK ${ }_{C}$ are directly involved in substrate specificity switching of the flagellar type III protein export apparatus ${ }^{47}$. Recent photo-crosslinking experiments have demonstrated that the conserved core domain of FliK directly binds to $\mathrm{FlhB}_{\mathrm{C}}{ }^{45}$. Similar protein-protein interactions have been observed in the injectisome ${ }^{55}$. These suggest that length control and substrate specificity switching mechanisms are conserved in both flagellar and injectisome systems. However, it remains unknown how the length measurement process by the secreted ruler is linked to the substrate specificity switching process of the type III protein export apparatus.

It has been reported that $\mathrm{FliK}_{\mathrm{L}}$ forms part of the ruler to determine hook length, but a deletion of residues 208-269 results in polyhooks with the filament attached ${ }^{42}$, having led to a hypothesis that residues 208-235 may contribute to efficient substrate specificity switching of the flagellar type III protein export apparatus. To verify this hypothesis, we introduced systematic deletions into $\mathrm{FliK}_{\mathrm{L}}$ and found that a deletion of residues 206-235 not only shortened hook length according to the size of deletion but also caused a loose hook length control (Fig. 2). The hook length control became much worse in the $f l i K(\Delta 206-255)$ and $f l i K(\Delta 206-265)$ mutants (Fig. 3c). The deletion of residues 206-265 considerably reduced the export switching function of $\mathrm{FliK}_{\mathrm{C}}$ (Fig $3 \mathrm{~d}, \mathrm{e}$ ). An insertion of 100 amino-acids between Glu-270 and Trp-271 residues in the core domain of FliK $\mathrm{C}_{\mathrm{C}}$ considerably improved the switching function of FliK $(\Delta 2-99+\Delta 206-265)$, thereby shortening the hook length considerably and increasing the probability of filament formation significantly (Figs. 4 and 5). Consistently, this inserted sequence allowed FliK $(\Delta 2-99+\Delta 206-265+$ I304pBPA $)$ to form a photo-crosslinked product with FlhB $_{\mathrm{C}}$ in a way similar to FliK(I304pBPA) (Fig. 4e). Therefore, we suggest that the inserted sequence of the suppressor mutant significantly increases the binding affinity of the core domain of $\mathrm{FliK}_{\mathrm{C}}$ for $\mathrm{FlhB}_{\mathrm{C}}$. Although FliK( $\left.\Delta 2-99\right)$ is not secreted via the flagellar type III protein export apparatus during hook assembly, it retains the ability to catalyze the substrate specificity switching of the flagellar type III protein export apparatus to a considerable degree ${ }^{49}$. Therefore, we suggest that $\mathrm{FliK}_{\mathrm{L}}$ is also required for efficient interaction between the core domain of $\mathrm{FliK}_{\mathrm{C}}$ and $\mathrm{FlhB}_{\mathrm{C}}$. When the length of FliK $_{\mathrm{L}}$ was shortened by deletions, the export switching activity of $\mathrm{FliK}_{\mathrm{C}}$ was reduced depending on the size of deletions (Fig. 3). Furthermore, when the linker length became longer by 40 amino-acids compared to the wild-type length, the switching function of $\mathrm{FliK}_{\mathrm{C}}$ became worse (Fig. 6). Therefore, we propose that a proper length of FliK $\mathrm{L}_{\mathrm{L}}$ between $\mathrm{FliK}_{\mathrm{N}}$ and $\mathrm{FliK}_{\mathrm{C}}$ may be important for $\mathrm{FliK}_{\mathrm{C}}$ to bind to $\mathrm{FlhB}_{\mathrm{C}}$ to switch the substrate specificity of the flagellar type III protein export apparatus. Assuming that FliK $_{\mathrm{N}}$ suppresses the switching activity of FliK $_{C}$ when FliK $_{N}$ gets close to $\mathrm{FliK}_{\mathrm{C}}$ via deletion of residues in $\mathrm{FliK}_{\mathrm{L}}$, it is also possible that FliK $\mathrm{L}_{\mathrm{L}}$ mas push $\mathrm{FliK}_{\mathrm{N}}$ away from FliK $_{C}$ to allow these two domains to fully exert their own functions. 
a

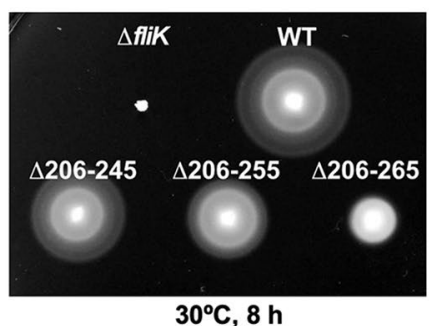

b

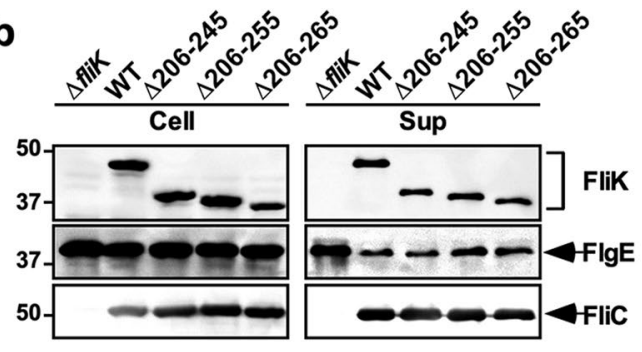

C
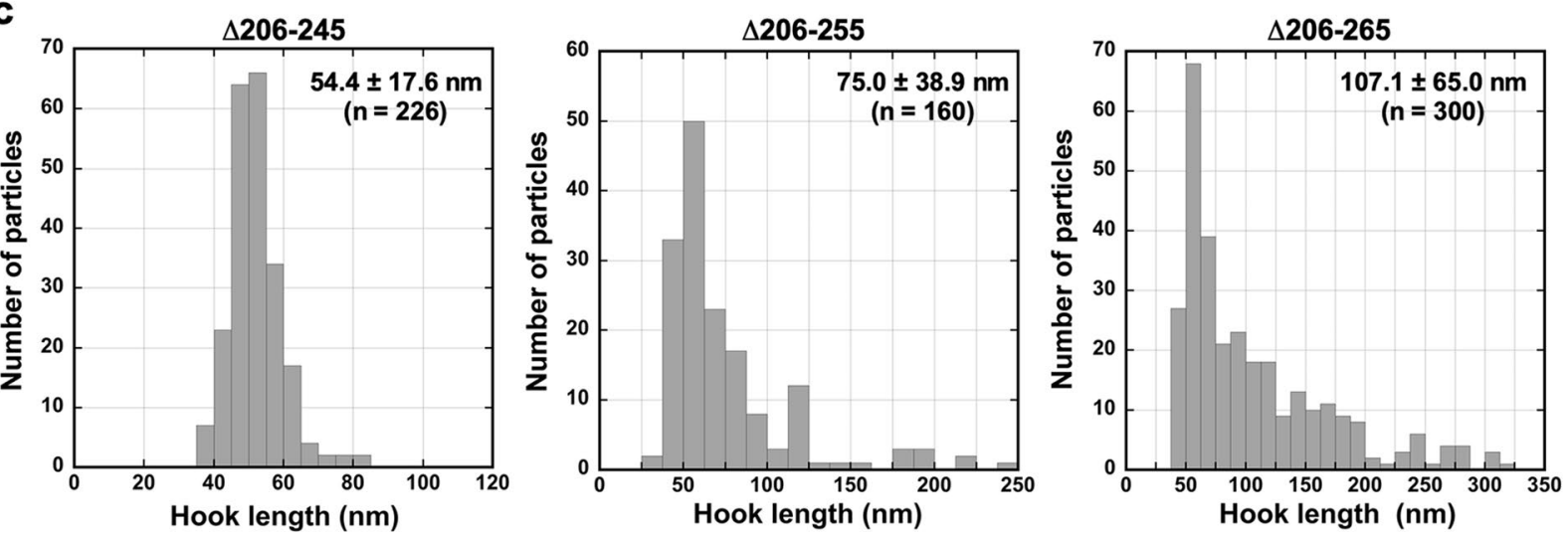

d

e

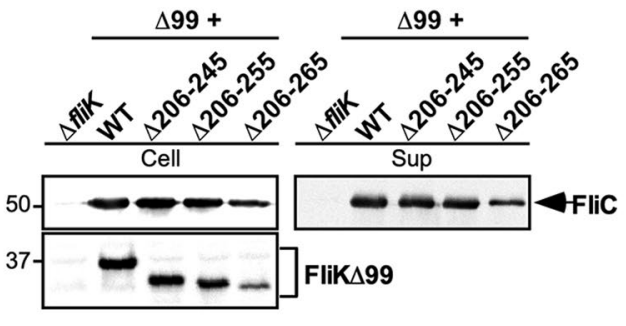

Figure 3. Effect of deletion of residues 206-245, 206-255 or 206-265 on FliK function. (a) Motility of TH8426

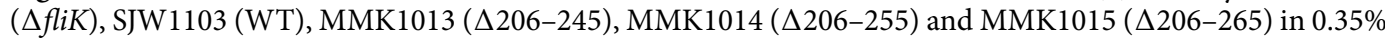
soft agar. Plates were incubated at $30^{\circ} \mathrm{C}$ for 8 hours. (b) Secretion assays of FliK, FlgE and FliC. Immunoblotting using polyclonal anti-FliK (1st row), anti-FlgE (2nd row) or anti-FliC (3rd row) antibody, of whole cell proteins (Cell) and culture supernatants (Sup) from the above strains. The regions of interest were cropped from original immunoblots shown in Fig. S7a in the Supplemental information using Photoshop CS6, and then the contrast and brightness were adjusted. The positions of molecular mass markers $(\mathrm{kDa})$ are indicated on the left. (c) Histograms of hook length distribution of MMK1013 ( $\Delta 206-245)$, MMK1014 $(\Delta 206-255)$ and MMK1015 ( $\Delta 206-265)$. (d) Motility of TH8426 harboring pTrc99AFF4 ( $\Delta$ fliK), pNM201 $(\Delta 99)$, pMMK1028 $(\Delta 99+\Delta 206-245)$, pMMK1029 $(\Delta 99+\Delta 206-255)$ or pMMK1030 $(\Delta 99+\Delta 206-265)$ in $0.35 \%$ soft agar containing $1 \mathrm{mM}$ IPTG. Plates were incubated at $30^{\circ} \mathrm{C}$ for 8 hours. (e) Secretion assay of FliC. Immunoblotting using polyclonal anti-FliC (1st row) or anti-FliK (2nd row) antibody, of whole cell proteins (Cell) and culture supernatants (Sup) from the above strains. The regions of interest were cropped from original immunoblots shown in Fig. S7b in the Supplemental information using Photoshop CS6, and then the contrast and brightness were adjusted. The positions of molecular mass markers $(\mathrm{kDa})$ are indicated on the left.

The core domain of FliK $\mathrm{C}_{\mathrm{C}}$ consists of four $\beta$-strands, $\beta 1, \beta 2, \beta 3$ and $\beta 4$ and two $\alpha$-helices, $\alpha 1$ and $\alpha 2$. Three parallel $\beta 1, \beta 3$ and $\beta 4$ strands and one anti-parallel $\beta 2$ strand form a hydrophobic core with the $\alpha 1$ and $\alpha 2$ helices (Fig. 4d) ${ }^{46}$. Highly conserved Val-302 and Ile-304 residues in the $\beta 2$ strand, which are critical for the switching function of $\mathrm{FliK}^{47}$, form hydrophobic interaction networks in $\mathrm{FliK}_{\mathrm{C}}{ }^{46}$. Photo-crosslinking experiments have shown that Val-302 and Ile-304 are in very close proximity to $\mathrm{FlhB}_{\mathrm{C}}$, suggesting that these two residues are exposed on the molecular surface of $\mathrm{FliK}_{\mathrm{C}}$ upon binding to $\mathrm{FlhB}_{\mathrm{C}}{ }^{45}$. Since FliK $(\Delta 2-99+\Delta 206-$ $265 \mathrm{SP}+\mathrm{I} 304 \mathrm{pBPA})$ formed a photo-crosslinked product with $\mathrm{FlhB}_{\mathrm{C}}$ whereas neither FliK $(\Delta 2-99+\mathrm{I} 304 \mathrm{pBPA})$ nor FliK $(\Delta 2-99+\Delta 206-265+\mathrm{I} 304 \mathrm{pBPA})$ did (Fig. 4e), this suggests that the inserted sequence of the suppressor mutant induces a conformational change of the $\mathrm{N}$-terminal portion of the core domain of FliK $\mathrm{C}_{\mathrm{C}}$ to allow Ile-304 to bind to $\mathrm{FlhB}_{\mathrm{C}}$. Therefore, we propose that $\mathrm{FliK}_{\mathrm{L}}$ may be required for efficient conformational rearrangements of $\mathrm{FliK}_{\mathrm{C}}$ to interact with $\mathrm{FlhB}_{\mathrm{C}}$. However, it is also possible that deletion of residues 206-265 makes FliK $\mathrm{N}_{\mathrm{N}}$ very close to $\mathrm{FliK}_{\mathrm{C}}$ to suppress the interaction of $\mathrm{FliK}_{\mathrm{C}}$ with $\mathrm{FlhB}_{\mathrm{C}}$ and that the inserted sequence of the suppressor mutant may push FliK $\mathrm{N}_{\mathrm{N}}$ away from FliK $\mathrm{C}$, allowing FliK to bind to $\mathrm{FlhB}_{\mathrm{C}}$. 

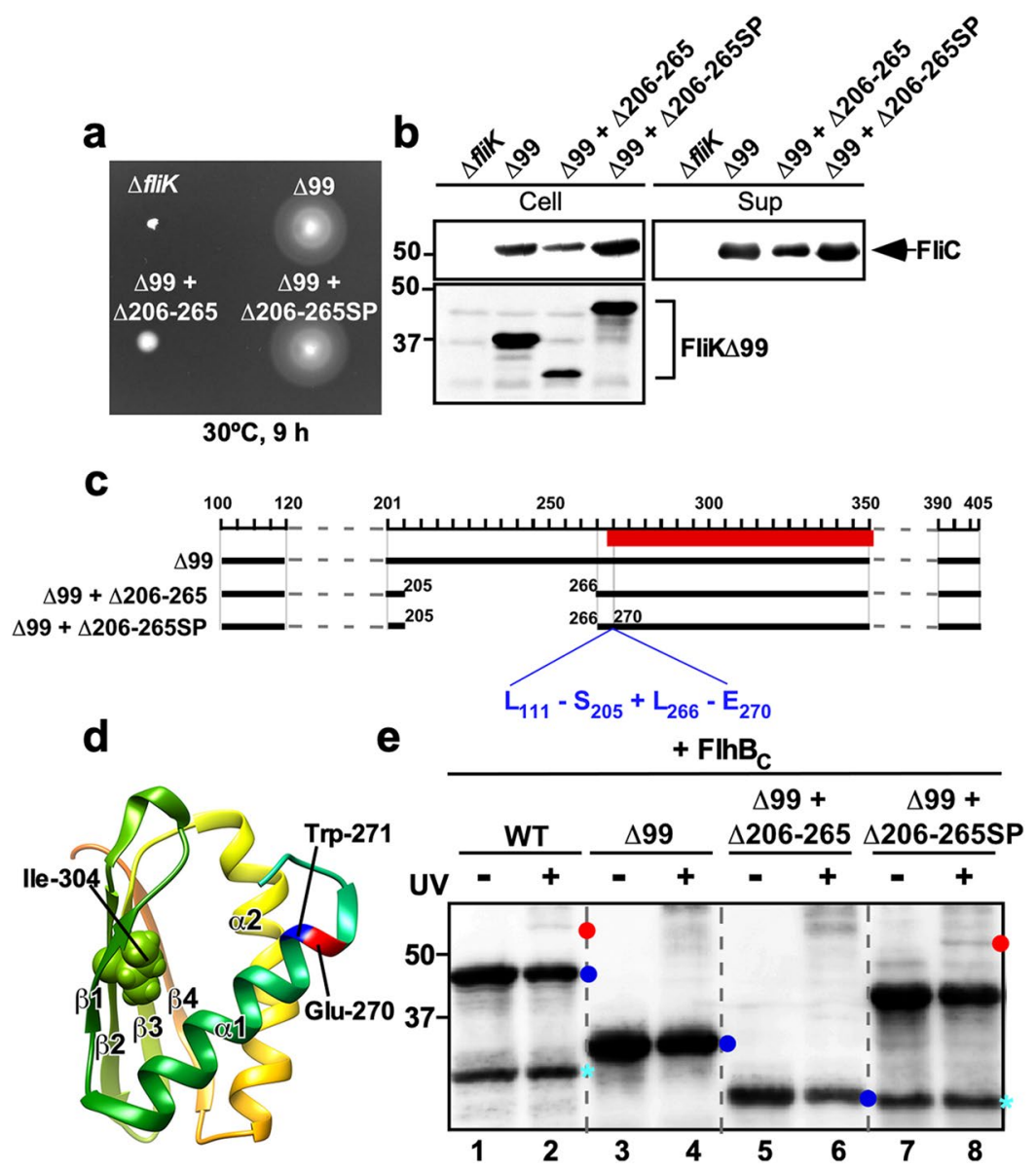

Figure 4. Isolation of pseudorevertants from the $f l i K(\Delta 99+\Delta 206-265)$ mutant. (a) Motility of TH8426 transformed with pTrc99A $(\Delta f l K)$, pNM201 $(\Delta 99)$, pMMK1030 $(\Delta 99+\Delta 206-265)$ or pMMK1030SP $(\Delta 99+\Delta 206-265 \mathrm{SP})$ in $0.35 \%$ soft agar containing $1 \mathrm{mM}$ IPTG. Plates were incubated at $30^{\circ} \mathrm{C}$ for 9 hours. (b) Secretion assay of FliC. Immunoblotting using polyclonal anti-FliC (1st row) or anti-FliK (2nd row) antibody, of whole cell proteins (Cell) and culture supernatants (Sup) prepared from the above strains. The regions of interest were cropped from original immunoblots shown in Fig. S8a in the Supplemental information using Photoshop CS6, and then the contrast and brightness were adjusted. The positions of molecular mass markers $(\mathrm{kDa})$ are indicated on the left. (c) Location of the intragenic suppressor insertion mutation on FliK $(\Delta 99+\Delta 206-265)$ and schematic bar diagram representations of FliK $\Delta 99$ products caused by a deletion of residues 206-265 and the intragenic suppressor insertion of residues 111-270 lacking residues 206-265 $\left(\mathrm{L}_{111}-\mathrm{S}_{205}+\mathrm{L}_{266}-\mathrm{E}_{270}\right)$ between Glu-270 and Trp-271 residues. Red bar indicates a core domain of FliK $\mathrm{C}_{\text {. }}$ (d) NMR structure of a core domain of FliK $_{\mathrm{C}}$ (PDB ID: 2RRL). The C $\alpha$ backbone is color-coded from green to orange, going through the rainbow colors from the $\mathrm{N}$ - to the $\mathrm{C}$-terminus. A highly conserved Ile-304 residue is involved in the interaction with FlhB. The inserted suppressor sequence is located between Glu-270 and Trp-271 residues. (e) Photo-crosslinking between FliK( $\Delta 2-99)$ and FlhB ${ }_{\mathrm{C}}$. E. coli BL21(DE3) cells coexpressing FliK(I304pBPA), FliK $(\Delta 99+\mathrm{I} 304 \mathrm{pBPA})$, FliK $(\Delta 99+\Delta 206-265+\mathrm{I} 304 \mathrm{pBPA})$ or FliK $(\Delta 99+\Delta 206-$ $265 \mathrm{SP}+\mathrm{I} 304 \mathrm{pBPA})$ with $\mathrm{FhB}_{\mathrm{C}}$ were UV-irradiated for $5 \mathrm{~min}(+)$ or not irradiated $(-)$, and then analyzed by immunoblotting with polyclonal anti-FliK antibody. The regions of interest were cropped from original immunoblots shown in Fig. S8b in the Supplemental information using Photoshop CS6, and then the contrast and brightness were adjusted. The positions of molecular mass markers $(\mathrm{kDa})$ are indicated on the left. The positions of free FliK and FliK-FlhB ${ }_{\mathrm{C}}$ photo-crosslinked products are shown by blue and red balls, respectively. C-terminal truncated variants of FliK are shown by cyan asterisk.

$\mathrm{FliK}_{\mathrm{C}}$ associates with and dissociates from $\mathrm{FliK}_{\mathrm{N}}$ in solution ${ }^{41}$. When $\mathrm{FliK}_{\mathrm{L}}$ adopts a fully extended conformation, the $\mathrm{N}$-terminal portion of the core domain of $\mathrm{FliK}_{\mathrm{C}}$ becomes disordered ${ }^{41}$. Because the length of the most extended polypeptide is $0.37 \mathrm{~nm}$ per residue, the stretch of FliK sequence inside the channel of the hook-basal body must be longer than 250 residues to measure the hook length of about $55 \mathrm{~nm}$ together with the rod length of $35 \mathrm{~nm}$. Therefore, we propose that $\mathrm{FliK}_{\mathrm{L}}$ may adopt a fully extended conformation when the hook length reaches about $55 \mathrm{~nm}$, allowing Val-302 and Ile-304 in the hydrophobic core domain of FliK $\mathrm{C}_{\mathrm{C}}$ to be in very close proximity to $\mathrm{FlhB}_{\mathrm{C}}$ to catalyze substrate specificity switching of the flagellar type III protein export apparatus. 
$\Delta 99$

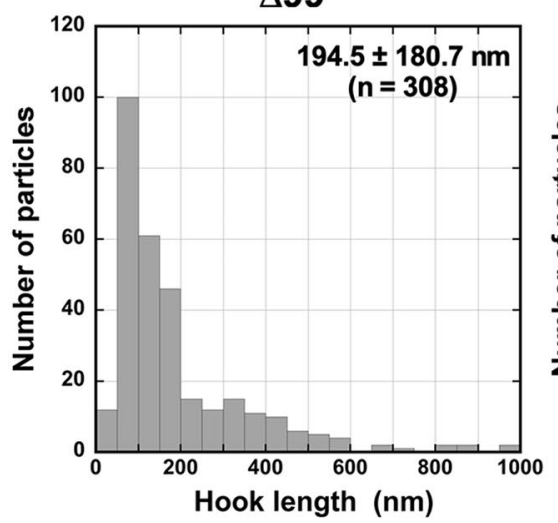

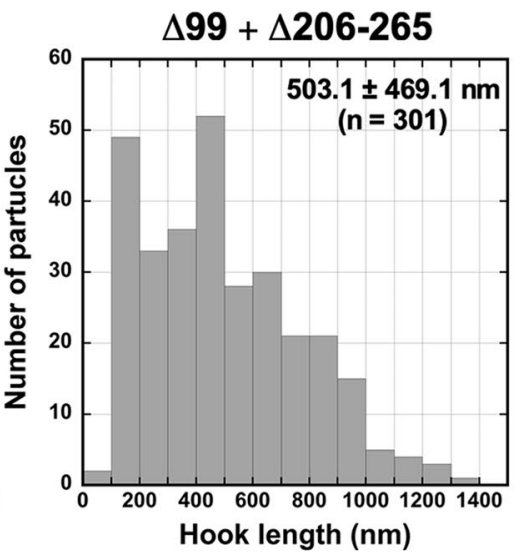

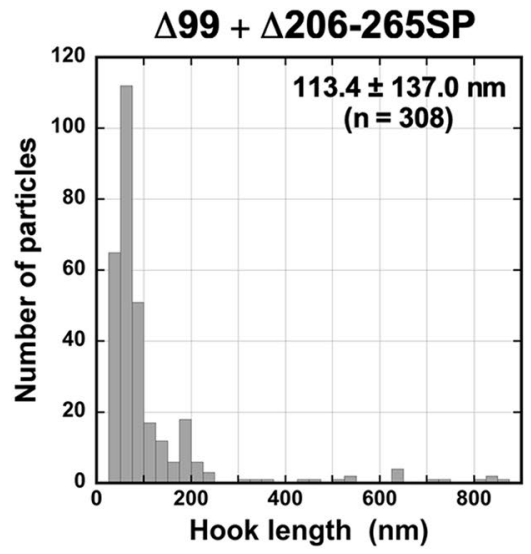

Figure 5. Effects of deletion of residues 206-265 and its intragenic suppressor insertion mutation on length distribution of the hooks produced by the $f(i K(\Delta 2-99)$ mutant. Histograms of hook length distribution of TH8426 harboring pNM201 $(\Delta 99)$, pMMK1030 $(\Delta 99+\Delta 206-265)$ or pMMK1030SP $(\Delta 99+\Delta 206-265 S P)$.

a

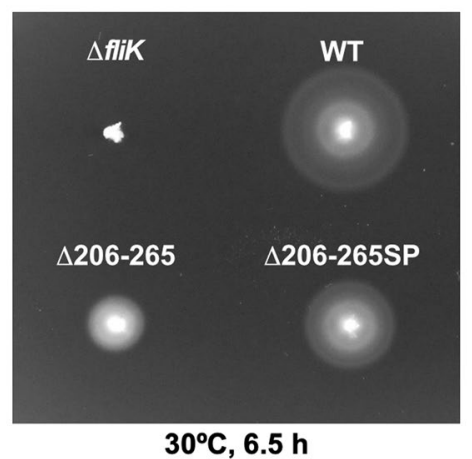

C

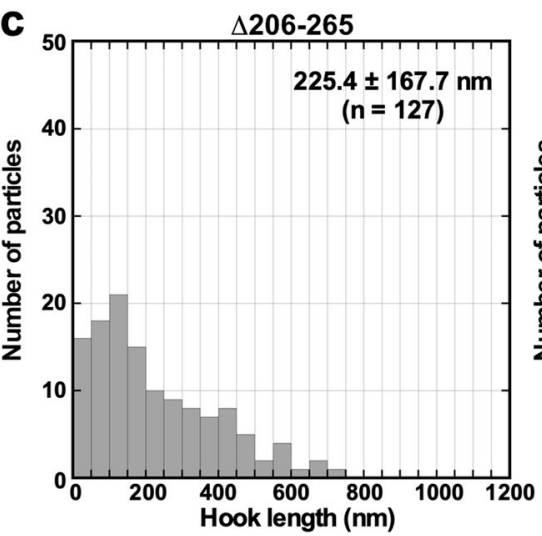

b

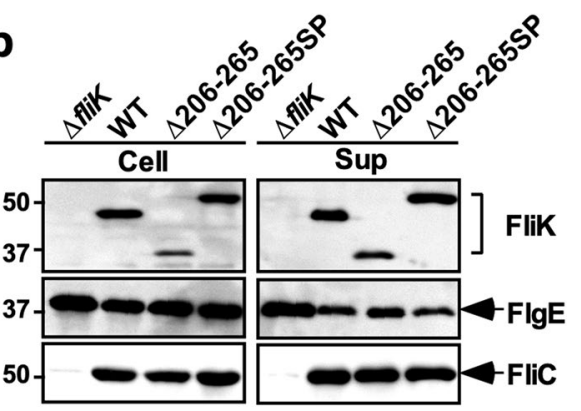

Figure 6. Effects of the inserted sequence of the intragenic $f l i K(\Delta 2-99+\Delta 206-265)$ suppressor mutant on length distribution of the hooks produced by the $f i K(\Delta 206-265)$ mutant. (a) Motility of TH8426 harboring

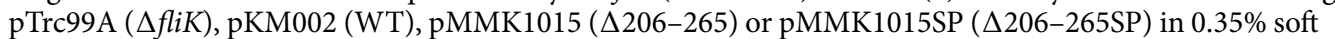
agar. Plates were incubated at $30^{\circ} \mathrm{C}$ for 6.5 hours. (b) Secretion assays of FlgE and FliC. Immunoblotting using polyclonal anti-FliK (1st row), anti-FlgE (2nd row) or anti-FliC (3rd row) antibody, of whole cell proteins (Cell) and culture supernatants (Sup) prepared from the above strains. The regions of interest were cropped from original immunoblots shown in Fig. S9 using Photoshop CS6, and then the contrast and brightness were adjusted. The positions of molecular mass markers $(\mathrm{kDa})$ are indicated on the left. (c) Histograms of hook length distribution of TH8426 harboring pMMK1015 or pMMK1015SP.

\section{Methods}

Bacterial strains, plasmids and media. Bacterial strains and plasmids used in this study are listed in Table 1 . To construct the Salmonella fliK( $\Delta 206-235)$, fliK( $\Delta 206-245)$, fliK( $\Delta 206-255)$ and $f l i K(\Delta 206-265)$ mutant strains, the $f l i K$ gene on the chromosome was replaced by the $f l i K(\Delta 206-235), f l i K(\Delta 206-245), f l i K(\Delta 206-255)$ 
and $f$ liK $(\Delta 206-265)$ alleles, using the $\lambda$ Red homologous recombination system ${ }^{56}$. L-broth contained $10 \mathrm{~g}$ of BactoTryptone, $5 \mathrm{~g}$ of yeast extract and $5 \mathrm{~g}$ of $\mathrm{NaCl}$ per liter. Soft agar plates contained $10 \mathrm{~g}$ of Bacto Tryptone, $5 \mathrm{~g}$ of $\mathrm{NaCl}$ and $0.35 \%$ Bacto-Agar per liter. Ampicillin was added at a final concentration of $100 \mu \mathrm{g} / \mathrm{ml}$ if necessary.

DNA manipulations. DNA manipulations were carried out as described ${ }^{57}$. A series of mutant variants of FliK with deletions within FliK $_{\mathrm{L}}$ were generated by inverse PCR using $\mathrm{pKM} 002^{48}$ or $\mathrm{pNM} 201^{44}$ as a template. The $f l i K(\Delta 206-265 S P)$ allele were generated by overlap PCR method. All of the $f l i K$ deletions were confirmed by DNA sequencing. DNA sequencing reactions were carried out using BigDye v3.1 (Applied Biosystems) and then the reaction mixtures were analyzed by a 3130 Genetic Analyzer (Applied Biosystems).

Motility assays in soft agar. Fresh colonies were inoculated onto $0.35 \%$ soft tryptone agar plates and incubated at $30^{\circ} \mathrm{C}$. At least seven independent measurements were carried out.

Secretion assays. Secretion assays were performed as described previously ${ }^{58}$. Salmonella cells were grown in 5 $\mathrm{ml} \mathrm{L-broth} \mathrm{containing} 100 \mu \mathrm{g} / \mathrm{ml}$ ampicillin at $30^{\circ} \mathrm{C}$ with shaking until the cell density had reached an $\mathrm{OD}_{600}$ of ca. $1.2-1.6 .1 .5 \mathrm{ml}$ of each culture was transferred into a $1.5 \mathrm{ml}$ Eppendorf tube. After centrifugation $(15,000 \mathrm{~g}, 5 \mathrm{~min}$, $4^{\circ} \mathrm{C}$ ), cell pellets and culture supernatants were collected, separately. The cells were resuspended in $\mathrm{OD}_{600} \times 250 \mu \mathrm{l}$ of SDS-loading buffer $(62.5 \mathrm{mM}$ Tris- $\mathrm{HCl}, \mathrm{pH} 6.8,2 \% \mathrm{SDS}, 10 \%$ glycerol, $0.001 \%$ bromophenol blue) containing $1 \mu \mathrm{l}$ of 2 -mercaptoethanol and heated at $95^{\circ} \mathrm{C}$ for $3 \mathrm{~min}$. Trichloroacetic acid was added to each culture supernatant at a final concentration of $10 \%$. After leaving on ice for $1 \mathrm{~h}$, proteins in the culture supernatants were precipitated by centrifugation at $20,000 \mathrm{~g}$ for $20 \mathrm{~min}$. Pellets were suspended in $\mathrm{OD}_{600}$ × $25 \mu \mathrm{l}$ of a Tris-SDS loading buffer (one volume of $1 \mathrm{M}$ Tris, nine volumes of $1 \times$ SDS loading buffer) containing $1 \mu \mathrm{l}$ of 2 -mercaptoethanol and heated at $95^{\circ} \mathrm{C}$ for $3 \mathrm{~min}$. After sodium dodecyl sulfate-polyacrylamide gel electrophoresis (SDS-PAGE), immunoblotting with polyclonal anti-FlgE, anti-FliC or anti-FliK antibody was carried out as described previously ${ }^{16}$. Detection was done with an ECL prime western blotting detection reagent (GE Healthcare). Chemiluminescence signals were captured by a Luminoimage analyzer LAS-3000 (GE Healthcare). The regions of interest were cropped from original immunoblots shown in the Supplemental information using a software, Photoshop CS6, and then the contrast and brightness were adjusted. At least three independent experiments were performed.

Electron microscopy. Osmotically shocked Salmonella cells were prepared described previously ${ }^{45}$. After centrifugation $\left(18,500 \mathrm{~g}, 30 \mathrm{~min}\right.$ ), the cell pellets were resuspended in $200 \mu \mathrm{l}$ of $\mathrm{H}_{2} \mathrm{O}$. Samples were applied to carbon-coated copper grids and were negatively stained with $1.0 \%(\mathrm{~W} / \mathrm{V})$ phosphotungstic acid, $\mathrm{pH}$ 7.0. Micrographs were recorded at a magnification of $\times 5,000$ with a JEM-1200EXII transmission electron microscope (JEOL, Tokyo, Japan) operating at $80 \mathrm{kV}$.

Hook-basal bodies and polyhook-basal bodies were isolated as described before ${ }^{27}$. Salmonella cells were grown in $5 \mathrm{l} \mathrm{L}$-broth containing ampicillin at $30^{\circ} \mathrm{C}$ with shaking until the cell density had reached an $\mathrm{OD}_{600}$ of ca. 1.0. The cells were harvested by centrifugation $\left(10,000 \mathrm{~g}, 10 \mathrm{~min}, 4^{\circ} \mathrm{C}\right)$ and suspended in $20 \mathrm{ml}$ of ice-cold $0.1 \mathrm{M}$ Tris- $\mathrm{HCl} \mathrm{pH}$ 8.0, $0.5 \mathrm{M}$ sucrose, followed by addition of EDTA and lysozyme at the final concentrations of $10 \mathrm{mM}$ and $0.1 \mathrm{mg} /$ $\mathrm{ml}$, respectively. The cell suspensions were stirred for $30 \mathrm{~min}$ at $4{ }^{\circ} \mathrm{C}$ and then were solubilized on ice for 1 hour by adding Triton X-100 and $\mathrm{MgSO}_{4}$ at final concentrations of $1 \%$ and $10 \mathrm{mM}$, respectively. The cell lysates were adjusted to $\mathrm{pH} 10.5$ with $5 \mathrm{M} \mathrm{NaOH}$ and then centrifuged $\left(10,000 \mathrm{~g}, 20 \mathrm{~min}, 4^{\circ} \mathrm{C}\right)$ to remove cell debris. After ultracentrifugation $\left(45,000 \mathrm{~g}, 60 \mathrm{~min}, 4^{\circ} \mathrm{C}\right)$, pellets were resuspended in $10 \mathrm{mM}$ Tris- $\mathrm{HCl}, \mathrm{pH} 8.0,5 \mathrm{mM} \mathrm{EDTA}, 1 \%$ Triton X-100, and the solution was loaded a $20-50 \%(\mathrm{w} / \mathrm{w})$ sucrose density gradient in $10 \mathrm{mM}$ Tris-HCl, $\mathrm{pH} 8.0,5 \mathrm{mM}$ EDTA, $1 \%$ Triton X-100. After ultracentrifugation $\left(49,100 \mathrm{~g}, 13 \mathrm{~h}, 4^{\circ} \mathrm{C}\right)$, intact flagella were collected and ultracentrifuged $\left(60,000 \mathrm{~g}, 60 \mathrm{~min}, 4^{\circ} \mathrm{C}\right)$. Pellets were suspended in $50 \mathrm{mM}$ glycine, $\mathrm{pH} 2.5,0.1 \%$ Triton X100, and were incubated at room temperature for $30 \mathrm{~min}$ to depolymerize flagellar filaments. After ultracentrifugation $\left(60,000 \mathrm{~g}, 60 \mathrm{~min}, 4^{\circ} \mathrm{C}\right)$, pellets were resuspended in $50 \mu \mathrm{l}$ of $10 \mathrm{mM}$ Tris- $\mathrm{HCl}, \mathrm{pH} 8.0,5 \mathrm{mM}$ EDTA, $0.1 \%$ Triton X100. Samples were negatively stained with $2 \%(\mathrm{w} / \mathrm{v})$ uranyl acetate. Samples were applied to carbon-coated copper grids and were negatively stained with $2 \%(\mathrm{w} / \mathrm{v})$ uranyl acetate. Electron micrographs were recorded with a JEM-1011 transmission electron microscope (JEOL, Tokyo, Japan) operated at $100 \mathrm{kV}$ and equipped with a F415 CCD camera (TVIPS, Gauting, Germany). Hook length was measured by ImageJ version 1.48 (National Institutes of Health).

Photo-crosslinking. E. coli BL21(DE3) cells harboring pEVOL ${ }^{59}$ and a pETDuet-based plasmid encoding both FliK with an amber mutation and $\mathrm{FlhB}_{\mathrm{C}}$ were exponentially grown at $30^{\circ} \mathrm{C}$ in L-broth containing $1 \mathrm{mM}$ pBPA. Then, $100 \mu \mathrm{M}$ IPTG and $0.02 \%$ arabinose were added and the incubation was continued until the culture density had reached an $\mathrm{OD}_{600}$ of ca. 1.4-1.5. Photo-crosslinking was carried out as described previously ${ }^{60}$. The cell pellets were harvested by centrifugation, suspended in SDS-loading buffer, and heated at $95^{\circ} \mathrm{C}$ for $3 \mathrm{~min}$. After SDS-PAGE, immunoblotting with polyclonal anti-FliK antibody was carried out. Detection was done with an ECL prime western blotting detection reagent. Chemiluminescence signals were captured by a Luminoimage analyzer LAS-3000. The regions of interest were cropped from original immunoblots shown in the Supplemental information using a software, Photoshop CS6, and then the contrast and brightness were adjusted. At least three independent experiments were performed.

\section{Data availability}

All data generated or analyzed during this study are included in this published article and its Supplementary Information files.

Received: 25 March 2019; Accepted: 2 January 2020;

Published online: 21 January 2020 


\section{References}

1. Nakamura, S. \& Minamino, T. Flagella-driven motility of bacteria. Biomolecules. 9, 279 (2019).

2. Hirano, T., Yamaguchi, S., Oosawa, K. \& Aizawa, S.-I. Roles of FliK and FlhB in determination of flagellar hook length in Salmonella typhimurium. J. Bacteriol. 176, 5439-5449 (1994).

3. Spöring, I. et al. Hook length of the bacterial flagellum is optimized for maximal stability of the flagellar bundle. PLOS Biol. 16, e2006989 (2018).

4. Minamino, T. Protein export through the bacterial flagellar type III export pathway. Biochim. Biophys. Acta. 1843, 1642-1648 (2014).

5. Ohnishi, K., Ohto, Y., Aizawa, S., Macnab, R. M. \& Iino, T. FlgD is a scaffolding protein needed for flagellar hook assembly in Salmonella typhimurium. J. Bacteriol. 176, 2272-2281 (1994).

6. Moriya, N., Minamino, T., Imada, K. \& Namba, K. Genetic analysis of the bacterial hook-capping protein FlgD responsible for hook assembly. Microbiology 157, 1354-1362 (2011).

7. Sakai, T., Inoue, Y., Terahara, N., Namba, K. \& Minamino, T. A triangular loop of domain D1 of FlgE is essential for hook assembly but not for the mechanical function. Biochem. Biophys. Res. Commun. 495, 1789-1794 (2018).

8. Ferris, H. U. \& Minamino, T. Flipping the switch: bringing order to flagellar assembly. Trends Microbiol. 14, 519-526 (2006).

9. Minamino, T., Imada, K. \& Namba, K. Mechanisms of type III protein export for bacterial flagellar assembly. Mol. BioSyst. 4, $1105-1115$ (2008).

10. Minamino, T. Hierarchical protein export mechanism of the bacterial flagellar type III protein export apparatus. FEMS Microbiol. lett. 365, fny117 (2018).

11. Kutsukake, K., Minamino, T. \& Yokoseki, T. Isolation and characterization of FliK-independent flagellation mutants from Salmonella typhimurium. J. Bacteriol. 176, 7625-7629 (1994).

12. Williams, A. W. et al. Mutations in fliK and flhB affecting flagellar hook and filament assembly in Salmonella typhimurium. J. Bacteriol. 178, 2960-2970 (1996).

13. Kutsukake, K. Hook-length control of the export-switching machinery involves a double-locked gate in Salmonella typhimurium flagellar morphogenesis. J. Bacteriol. 179, 1268-1273 (1997).

14. Hirano, T., Mizuno, S., Aizawa, S.-I. \& Hughes, K. T. Mutations in Flk, FlgG, FlhA, and FlhE that affect the flagellar type III secretion specificity switch in Salmonella enterica. J. Bacteriol. 181, 3938-3949 (2009).

15. Minamino, T., Iino, T. \& Kutsukake, K. Molecular characterization of the Salmonella typhimurium flhB operon and its protein products. J. Bacteriol. 176, 7630-7637 (1994).

16. Minamino, T. \& Macnab, R. M. Components of the Salmonella flagellar export apparatus and classification of export substrates. J. Bacteriol. 181, 1388-1394 (1999).

17. Abrusci, P. et al. Architecture of the major component of the type III secretion system export apparatus. Nat. Struct. Mol. Biol. 20, 99-104 (2013).

18. Terahara, N. et al. Insight into structural remodeling of the FlhA ring responsible for bacterial flagellar type III protein export. Sci. Adv. 4, eaao7054 (2018)

19. Minamino, T. \& Macnab, R. M. Interactions among components of the Salmonella flagellar export apparatus and its substrates. Mol. Microbiol. 35, 1052-1064 (2000).

20. Minamino, T. et al. Role of the C-terminal cytoplasmic domain of FlhA in bacterial flagellar type III protein export. J. Bacteriol. 192, 1929-1936 (2010).

21. Minamino, T., Morimoto, Y. V., Hara, N. \& Namba, K. An energy transduction mechanism used in bacterial flagellar type III protein export. Nat. Commun. 2, 475 (2011).

22. Bange, G. et al. FlhA provides the adaptor for coordinated delivery of late flagella building blocks to the type III secretion system. Proc. Natl. Acad. Sci. USA 107, 11295-11300 (2010).

23. Minamino, T. et al. Interaction of a bacterial flagellar chaperone FlgN with FlhA is required for efficient export of its cognate substrates. Mol. Microbiol. 83, 775-788 (2012).

24. Kinoshita, M., Hara, N., Imada, K., Namba, K. \& Minamino, T. Interactions of bacterial chaperone-substrate complexes with FlhA contribute to co-ordinating assembly of the flagellar filament. Mol. Microbiol. 90, 1249-1261 (2013).

25. Xing, Q. et al. Structure of chaperone-substrate complexes docked onto the export gate in a type III secretion system. Nat. Commun. 9, 1773.

26. Minamino, T. et al. FliH and FliI ensure efficient energy coupling of flagellar type III protein export in Salmonella. MicrobiologyOpen 5, 424-435 (2016).

27. Inoue, Y., Morimoto, Y. V., Namba, K. \& Minamino, T. Novel insights into the mechanism of well-ordered assembly of bacterial flagellar proteins in Salmonella. Sci. Rep. 8, 1787 (2018).

28. Minamino, T. \& Macnab, R. M. Domain structure of Salmonella FlhB, a flagellar export component responsible for substrate specificity switching. J. Bacteriol. 182, 4906-4919 (2000).

29. Fraser, G. M. et al. Substrate specificity of type III flagellar protein export in Salmonella is controlled by subdomain interactions in FlhB. Mol. Microbiol. 48, 1043-1057 (2003).

30. Ferris, H. U. et al. FlhB regulates ordered export of flagellar components via autocleavage mechanism. J. Biol. Chem. 280, 41236-41242 (2005).

31. Evans, L. D., Poulter, S., Terentjev, E. M., Hughes, C. \& Fraser, G. M. A chain mechanism for flagellum growth. Nature 504, 287-290 (2013).

32. McMurry, J. L. et al. Weak interactions between Salmonella enterica FlhB and other flagellar export apparatus proteins govern type III secretion dynamics. PLOS One 10, e0134884 (2015).

33. Inoue, Y. et al. Structural insight into the substrate specificity switch mechanism of the type III protein export apparatus. Structure 27, 965-976 (2019).

34. Aldridge, P., Karlinsey, J. E., Becker, E., Chevance, F. F. \& Hughes, K. T. Flk prevents premature secretion of the anti sigma factor FlgM into the preiplasm. Mol. Microbiol. 60, 630-642 (2006).

35. Minamino, T., González-Pedrajo, B., Yamaguchi, K., Aizawa, S.-I. \& Macnab, R. M. FliK, the protein responsible for flagellar hook length control in Salmonella, is exported during hook assembly. Mol. Microbiol. 34, 295-304 (1999).

36. Erhardt, M. et al. The role of the FliK molecular ruler in hook-length control in Salmonella enterica. Mol. Microbiol. 75, 1272-1284 (2010).

37. Erhardt, M., Singer, H. M., Wee, D. H., Keener, J. P. \& Hughes, K. T. An infrequent molecular ruler controls flagellar hook length in Salmonella enterica. EMBO J. 30, 2948-2961 (2011).

38. Uchida, K. \& Aizawa, S.-I. The flagellar soluble protein FliK determines the minimal length of the hook in Salmonella enterica serovar Typhimurium. J. Bacteriol. 196, 1753-1758 (2014).

39. Kawagishi, I., Homma, M., Williams, A. W. \& Macnab, R. M. Characterization of the flagellar hook length control protein of Salmonella typhimurium and Escherichia coli. J. Bacteriol. 178, 2954-2959 (1996).

40. Minamino, T. et al. Domain organization and function of Salmonella FliK, a flagellar hook-length control protein. J. Mol. Biol. 341, 491-502 (2004).

41. Kodera, N., Uchida, K., Ando, T. \& Aizawa, S.-I. Two-ball structure of the flagellar hook-length control protein FliK as revealed by high-speed atomic force microscopy. J. Mol. Biol. 427, 406-414 (2015).

42. Shibata, S. et al. FliK regulates flagellar hook length as an internal ruler. Mol. Microbiol. 64, 1404-1415 (2007). 
43. Moriya, N., Minamino, T., Hughes, K. T., Macnab, R. M. \& Namba, K. The type III flagellar export specificity switch is dependent on FliK ruler and a molecular clock. J. Mol. Biol. 359, 466-477 (2006).

44. Minamino, T., Moriya, N., Hirano, T., Hughes, K. T. \& Namba, K. Interaction of FliK with the bacterial flagellar hook is required for efficient export specificity switching. Mol. Microbiol. 74, 239-251 (2009).

45. Kinoshita, M., Aizawa, S.-I., Inoue, Y., Namba, K. \& Minamino, T. The role of intrinsically disordered C-terminal region of FliK in substrate specificity switching of the bacterial flagellar type III export apparatus. Mol. Microbiol. 105, 572-588 (2017)

46. Mizuno, S., Amida, H., Kobayashi, N., Aizawa, S.-I. \& Tate, S. The NMR structure of FliK, the trigger for the switch of substrate specificity in the flagellar type III secretion apparatus. J. Mol. Biol. 409, 558-573 (2011).

47. Minamino, T., Ferris, H. U., Morioya, N., Kihara, M. \& Namba, K. Two parts of the T3S4 domain of the hook-length control protein FliK are essential for the substrate specificity switching of the flagellar type III export apparatus. J. Mol. Biol. 362, 1148-1158 (2006).

48. Muramoto, K., Makishima, S., Aizawa, S.-I. \& Macnab, R. M. Effect of cellular level of FliK on flagellar hook and filament assembly in Salmonella typhimurium. J. Mol. Biol. 277, 871-882 (1998).

49. Hirano, T., Shibata, S., Ohnishi, K., Tani, T. \& Aizawa, S. N-terminal signal region of FliK is dispensable for length control of the flagellar hook. Mol. Microbiol. 56, 346-360 (2005).

50. Kubori, T. et al. Supramolecular structure of the Salmonella typhimurium type III protein secretion system. Science 280, 602-605 (1998).

51. Journet, L., Agrain, C., Broz, P. \& Cornelis, G. R. The needle length of bacterial injectisomes is determined by a molecular ruler. Science 302, 1757-1760 (2003).

52. Wee, D. H. \& Hughes, K. T. Molecular ruler determines needle length for the Salmonella Spi-1 injectisome. Proc. Natl. Acad. Sci. USA 112, 4098-103 (2015)

53. Agrain, C. et al. Characterization of a type III secretion substrate specificity switch (T3S4) domain in YscP from Yersinia enterocolitica. Mol. Microbiol. 56, 54-67 (2005).

54. Bergeron, J. R. et al. The structure of a type 3 secretion system (T3SS) ruler protein suggests a molecular mechanism for needle length sensing. J. Biol. Chem. 291, 1676-1691 (2016).

55. Ho, O. et al. Characterization of the ruler protein interaction interface on the substrate specificity switch protein in the Yersinia type III secretion system. J. Biol. Chem. 292, 3299-3311 (2017).

56. Datsenko, K. A. \& Wanner, B. L. One-step inactivation of chromosomal genes in Escherichia coli K-12 using PCR products. Proc. Natl, Acad. Sci. USA 97, 6640-6645 (2000).

57. Saijo-Hamano, Y., Minamino, T., Macnab, R. M. \& Namba, K. Structural and functional analysis of the C-terminal cytoplasmic domain of FlhA, an integral membrane component of the type III flagellar protein export apparatus in Salmonella. J. Mol. Biol. 343, $457-466$ (2004).

58. Minamino, T., Kinoshita, M. \& Namba, K. Fuel of the bacterial flagellar type III protein export apparatus. Methods Mol. Biol. 1593, 3-16 (2017).

59. Young, T. S., Ahmad, I., Yin, J. A. \& Schultz, P. G. An enhanced system for unnatural amino acid mutagenesis in E. coli. J. Mol. Biol. 395, 361-374 (2010).

60. Hara, N., Morimoto, Y. V., Kawamoto, A., Namba, K. \& Minamino, T. Interaction of the extreme N-terminal region of FliH with FlhA is required for efficient bacterial flagellar protein export. J. Bacteriol. 194, 5353-5360 (2012).

61. Yamaguchi, S., Fujita, H., Sugata, K., Taira, T. \& Iino, T. Genetic analysis of H2, the structural gene for phase-2 flagellin in Salmonella. J. Gen. Microbiol. 130, 255-265 (1984).

62. Ohnishi, K., Fan, F., Schoenhals, G. J., Kihara, M. \& Macnab, R. M. The FliO, FliP, FliQ, and FliR proteins of Salmonella typhimurium: putative components for flagellar assembly. J. Bacteriol. 179, 6092-6099 (1997).

\section{Acknowledgements}

We acknowledge Prof. P.G. Schultz for his kind gift of pEVOL. This work was supported in part by JSPS KAKENHI Grant Numbers JP18K14638 (to M.K.), JP25000013 (to K.N.), and JP26293097 and JP19H03182 (to T.M.) and MEXT KAKENHI Grant Number JP15H01640 (to T.M.). This work has also been partially supported by JEOL YOKOGUSHI Research Alliance Laboratories of Osaka University to K.N.

\section{Author contributions}

M.K., N.K., S.I.A. and T.M. conceived and designed research; M.K., S.T., Y.I., S.I.A. and T.M. preformed research; M.K., S.T., Y.I., S.I.A. and T.M. analysed the data; and M.K., K.N., S.I.A. and T.M. wrote the paper based on discussion with other authors.

\section{Competing interests}

The authors declare no competing interests.

\section{Additional information}

Supplementary information is available for this paper at https://doi.org/10.1038/s41598-020-57782-5.

Correspondence and requests for materials should be addressed to T.M.

Reprints and permissions information is available at www.nature.com/reprints.

Publisher's note Springer Nature remains neutral with regard to jurisdictional claims in published maps and institutional affiliations.

Open Access This article is licensed under a Creative Commons Attribution 4.0 International

License, which permits use, sharing, adaptation, distribution and reproduction in any medium or format, as long as you give appropriate credit to the original author(s) and the source, provide a link to the Creative Commons license, and indicate if changes were made. The images or other third party material in this article are included in the article's Creative Commons license, unless indicated otherwise in a credit line to the material. If material is not included in the article's Creative Commons license and your intended use is not permitted by statutory regulation or exceeds the permitted use, you will need to obtain permission directly from the copyright holder. To view a copy of this license, visit http://creativecommons.org/licenses/by/4.0/.

(c) The Author(s) 2020 